Journal of Bangladesh Chemical Society, Vol. 24(2), 209-214, 2011.

DOI: $10.3329 / j b c s . v 24 i 2.9710$

\title{
SYNTHESIS AND CHARACTERIZATION OF THREE SANDWICH COMPLEXES OF ZIRCONIUM WITH DISUBSTITUTED INDENYL LIGANDS
}

\author{
KALIPADA KUNDU* AND ALEXANDER REB
}

Department of Chemistry, Bayreuth University, D-95440 Bayreuth, Germany

\section{Abstract}

The preparation of three sandwich complexes of zirconium $(\mathbf{1 , 2 , 3})$ with disubstituted indenyl ligands and their characterization using ${ }^{1} \mathrm{H},{ }^{13} \mathrm{C}$ and ${ }^{29} \mathrm{Si}-\mathrm{NMR}$ and mass spectroscopy is described.

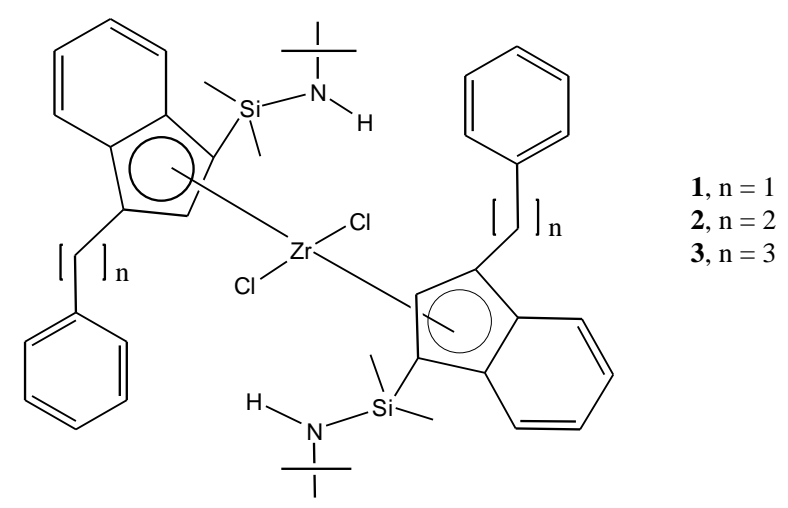

$(1,2,3)$

\section{Introduction}

The chemistry of sandwich and half-sandwich complexes of zirconium and titanium is gaining increasing interest for their application as catalyst precursors for catalytic polymerization of olefins ${ }^{1-5}$. We have earlier reported several amido functionalized halfsandwich complexes of these metals and their use as catalyst precursors for homogeneous ethylene polymerization ${ }^{6}$. In this paper we report the synthesis and spectroscopic characterization of another three new sandwich complexes of zirconium.

\section{Experimental}

The work was carried out using the standard Schlenk technique and dried argon was used to make inert atmosphere. The solvents were dried and distilled before use. All starting materials were commercially available and used without further purification. The spectrometers Bruker ARX 250, AC 300 and DRX 500 were used for recording the NMR spectra. The chemical shifts in the ${ }^{1} \mathrm{H}-\mathrm{NMR}$ spectra are referred to the residual proton signal of the solvent $\left(\delta=7.24 \mathrm{ppm}\right.$ for $\mathrm{CDCl}_{3}, \delta=7.15 \mathrm{ppm}$ for $\left.\mathrm{C}_{6} \mathrm{D}_{6}\right)$ and in the ${ }^{13} \mathrm{C}$ -

* Corresponding author. Present address: Department of Chemistry, Jahangirnagar University, Savar, Dhaka1342, Bangladesh. E-mail: kalipadakundu@yahoo.com 
NMR spectra to the solvent signal $\left(\delta=77.0 \mathrm{ppm}\right.$ for $\mathrm{CDCl}_{3}, \delta=128.0 \mathrm{ppm}$ for $\mathrm{C}_{6} \mathrm{D}_{6}$ ). $\mathrm{SiMe}_{4}(\delta=0.0)$ was used as an external standard for ${ }^{29} \mathrm{Si}-\mathrm{NMR}$ spectra. The mass spectra were recorded with a varian MAT $\mathrm{CH} 7$ instrument.

General procedure for the preparation of the ligand precursors (disubstituted indenes),

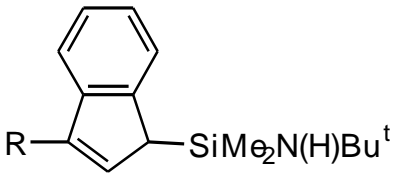

$$
\left(\mathrm{R}=\mathrm{CH}_{2} \mathrm{Ph}, \mathrm{CH}_{2} \mathrm{CH}_{2} \mathrm{Ph}, \mathrm{CH}_{2} \mathrm{CH}_{2} \mathrm{CH}_{2} \mathrm{Ph}\right)
$$

These were prepared by successive reactions shown in Scheme 1 following the procedure described in $\operatorname{ref}^{6}$.<smiles>C1=Cc2ccccc2C1</smiles>

(indene)

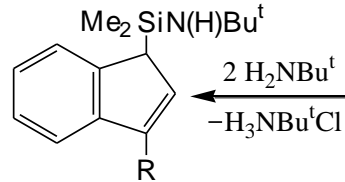

(ligand precursors)

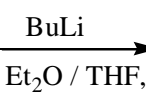
$-\mathrm{BuH}$ B) $\mathrm{Bu}^{\mathrm{t}}$ $-\mathrm{H}_{3} \mathrm{NBu}^{\mathrm{t}} \mathrm{Cl}$<smiles>[R]C1=C([Ge]Cl)C([Si](C)(Cl)Cl)c2ccccc21</smiles><smiles>[R]C1C=Cc2ccc(Br)cc21</smiles>
$-\mathrm{BuH}$ $\downarrow \mathrm{Et}_{2} \mathrm{O}$<smiles>[R]c1cccc2ccccc12</smiles>

Scheme 1. Synthesis of the ligand precursors, disubstituted indenes

$$
\left(\mathrm{R}=\mathrm{CH}_{2} \mathrm{Ph}, \mathrm{CH}_{2} \mathrm{CH}_{2} \mathrm{Ph}, \mathrm{CH}_{2} \mathrm{CH}_{2} \mathrm{CH}_{2} \mathrm{Ph}\right)
$$

General procedure for the preparation of the sandwich complexes

Diethyl ether solution of the appropriate ligand precursor $(100 \mathrm{mmol})$ was taken in a Schlenk flask and was cooled to $-78^{\circ} \mathrm{C}$ by immersing the flask in a bath of dry ice/acetone. Equimolar amount of n-butyllithium was slowly added to it and the mixture was stirred for $8 \mathrm{hrs}$ at room temperature. The solution of the resulting lithiated ligand was again cooled to $-78^{\circ} \mathrm{C}$ and ether solution of $\mathrm{ZrCl}_{4}(50 \mathrm{mmol})$ was slowly added with stirring. After completion of addition, the reaction mixture was allowed to reach room temperature and stirred for another $12 \mathrm{hrs}$. The precipitated $\mathrm{LiCl}$ was removed by filtration over $\mathrm{Na}_{2} \mathrm{SO}_{4}$ and the clear filtrate was concentrated and left overnight at $-78^{\circ} \mathrm{C}$ for crystallization. Orange yellow crystals of the sandwich complex separated which were collected and dried under vacuum. Yield: $62-75 \%$. Table-1 shows their mass and NMR spectroscopic data.

\section{Results and Discussion}


Three new sandwich complexes of zirconium $(\mathbf{1}, \mathbf{2}, \mathbf{3})$ were prepared from reactions of $\mathrm{ZrCl}_{4}$ with 2 molar equivalents of the lithiated ligands (details given in the experimental section). Scheme 2 shows the reactions involved in their preparation. In the first step the ligand precursor is reacted with equimolar amount of butyllithium to form the lithiated ligand which in the second step reacts with half molar equivalent of zirconium tetrachloride to form the corresponding sandwich complex.
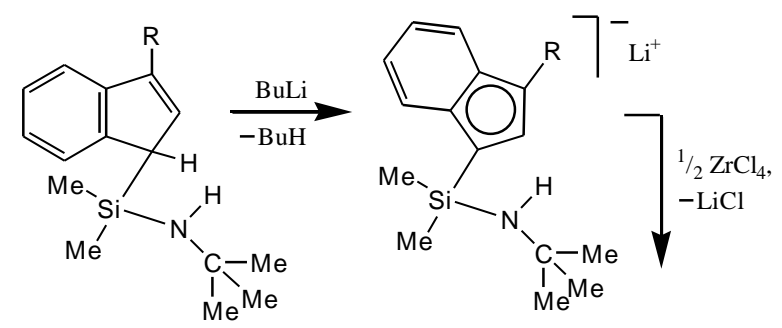

(ligand precursors)

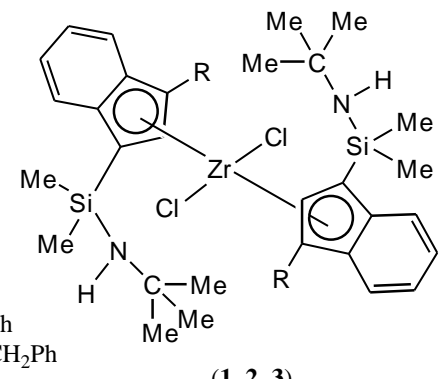

2, $\mathrm{R}=\mathrm{CH}_{2} \mathrm{CH}_{2} \mathrm{Ph}$
3, $\mathrm{R}=\mathrm{CH}_{2} \mathrm{CH}_{2} \mathrm{CH}_{2} \mathrm{Ph}$

$(1,2,3)$

Scheme 2. Reactions involved in the preparation of complexes 1, 2, 3

${ }^{1} \mathrm{H},{ }^{13} \mathrm{C}$ and ${ }^{29} \mathrm{Si}-\mathrm{NMR}$ and mass spectroscopy were used for the characterization of these complexes. The data are listed in Table 1 and characterization of complex $\mathbf{1}$ is discussed below in details. 


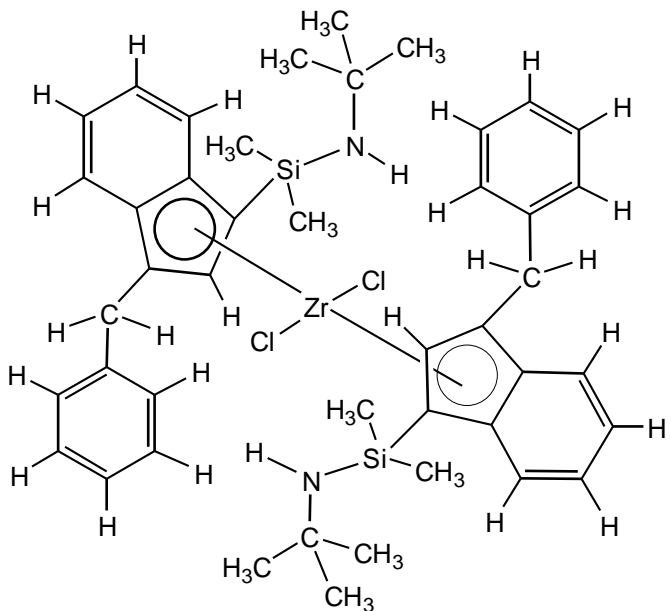

1

In the aliphatic region of the ${ }^{1} \mathrm{H}-\mathrm{NMR}$ spectrum of $\mathbf{1}$ signals for the two diastereotopic methyl groups attached to silicon were detected at $\delta=0.75$ and $0.88 \mathrm{ppm}$ as two sharp single peaks of equal intensity. The three methyl groups of the tert-butyl group were homotopic and form one singlet with a signal intensity of nine protons at $\delta=1.31 \mathrm{ppm}$. The signal for the $\mathrm{N}-\mathrm{H}$ proton was at $\delta=6.65 \mathrm{ppm}$. The peak for the $\mathrm{CH}_{2}$ protons was a multiplet centered at $\delta=4.36 \mathrm{ppm}$ and signals for all $\mathrm{C}-\mathrm{H}$ (aromatic) protons were observed in the region $\delta=7.23-8.32 \mathrm{ppm}$ as another multiplet with the proper intensity ratio for ten protons.

In the J-modulated ${ }^{13} \mathrm{C}$-NMR spectrum of $\mathbf{1}$ (Fig.1) the signals with negative phase at $\delta=$ $141.8,138.2,135.1,132.1$ and $124.0 \mathrm{ppm}$ were attributed to the quaternary carbon atoms present in the cyclopentadienyl and phenyl rings and signals for $\mathrm{CH}$ resonances of these rings appeared with positive phase at $\delta=128.3,128.2,128.0,127.7,126.6,126.5,126.4$, 126.0125 .3 and $124.3 \mathrm{ppm}$. The aliphatic area exhibited the singlet signal with positive phase at $\delta=33.8 \mathrm{ppm}$ for the three homotopic methyl carbon atoms of the tert-butyl group. Signals for the diastereotopic carbon atoms of the two methyl groups attached to silicon appeared with positive phase at $\delta=3.1$ and $3.7 \mathrm{ppm}$ and the signal for the $\mathrm{CH}_{2}$ carbon appeared with negative phase at $\delta=34.5 \mathrm{ppm}$. The quaternary carbon of the tertbutyl group gave a signal with negative phase at $\delta=49.8 \mathrm{ppm}$. 


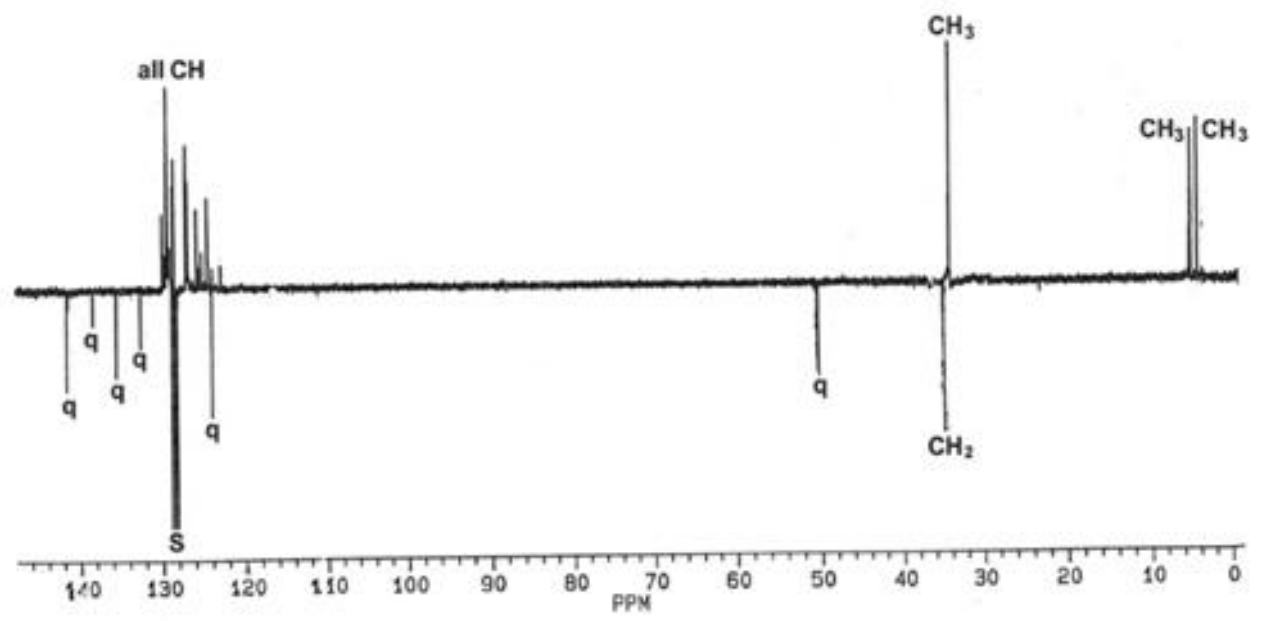

Fig. 1. J-modulated ${ }^{13} \mathrm{C}$-NMR spectrum of complex 1 
Table 1: ${ }^{1} \mathrm{H},{ }^{13} \mathrm{C},{ }^{29} \mathrm{Si}-\mathrm{NMR}$ and mass spectral data of the prepared sandwich complexes.

\begin{tabular}{|c|c|c|c|c|}
\hline $\begin{array}{c}\text { Comp } \\
\text { lex }\end{array}$ & ${ }^{1} \mathrm{H}-\mathrm{NMR}$ (ppm) & ${ }^{13} \mathrm{C}-\mathrm{NMR}$ (ppm) & $\begin{array}{c}{ }^{29} \mathrm{Si}-\mathrm{NMR} \\
(\mathrm{ppm})\end{array}$ & Mass spectrum (m/z) \\
\hline 1 & $\begin{array}{l}0.75(\mathrm{~s}, \mathrm{SiMe}), 0.88 \\
(\mathrm{~s}, \mathrm{SiMe}), 1.31(\mathrm{~s}, \\
\left.\mathrm{CMe}_{3}\right), 4.36(\mathrm{~m}, \\
\left.\mathrm{CH}_{2}\right), 6.65(\mathrm{~s}, \mathrm{NH}), \\
7.23-8.32(\mathrm{~m}, \mathrm{Ar}-\mathrm{H})\end{array}$ & $\begin{array}{l}\mathrm{C}_{\mathrm{q}}: 141.8,138.2, \\
135.1,132.1,124.0, \\
49.8 ; \mathrm{CH}: 128.3, \\
128.2,128.0,127.7, \\
126.6,126.5,126.4, \\
126.0,125.3,124.3 ; \\
\mathrm{CH}_{2}: 34.5 ; \mathrm{CH}_{3}: 33.8, \\
3.7,3.1\end{array}$ & -11.1 & $\begin{array}{l}830\left[\mathrm{M}^{+}\right], 700\left[\mathrm{M}^{+}-\right. \\
\left.\mathrm{Me}_{2} \mathrm{SiNHBu}^{\mathrm{t}}\right], 685 \\
{\left[\mathrm{M}^{+}-\mathrm{Me}_{2} \mathrm{SiNHBu}^{\mathrm{t}}-\mathrm{Me}\right]}\end{array}$ \\
\hline 2 & $\begin{array}{l}0.74(\mathrm{~s}, \mathrm{SiMe}), 0.87 \\
(\mathrm{~s}, \mathrm{SiMe}), 1.40(\mathrm{~s}, \\
\left.\mathrm{CMe}_{3}\right), 2.70-3.61(\mathrm{~m}, \\
\left.\mathrm{CH}_{2}-\mathrm{CH}_{2}\right), 6.25(\mathrm{~s}, \\
\mathrm{NH}), 6.85-8.21(\mathrm{~m}, \\
\mathrm{Ar}-\mathrm{H})\end{array}$ & $\begin{array}{l}\mathrm{C}_{\mathrm{q}}: 141.2,139.8, \\
138.6,134.3,131.7, \\
49.4 ; \mathrm{CH}: 128.7, \\
128.3,128.1,127.6, \\
126.4,126.2,125.0, \\
124.4,123.3,118.6 ; \\
\mathrm{CH}_{2}: 35.3,29.8 ; \mathrm{CH}_{3}: \\
33.6,3.7,2.0\end{array}$ & -11.2 & $\begin{array}{l}858\left[\mathrm{M}^{+}\right], 808\left[\mathrm{M}^{+}-\right. \\
\mathrm{Me}-\mathrm{Cl}], 728\left[\mathrm{M}^{+}-\right. \\
\left.\mathrm{Me}_{2} \mathrm{SiNHBu}\right], 642 \\
{\left[\mathrm{M}^{+}-\mathrm{Me}_{2} \mathrm{SiNHBu}^{\mathrm{t}}-\right.} \\
\mathrm{Me}-2 \mathrm{Cl}]\end{array}$ \\
\hline 3 & $\begin{array}{l}0.76(\mathrm{~s}, \mathrm{SiMe}), 0.86 \\
(\mathrm{~s}, \mathrm{SiMe}), 1.35(\mathrm{~s}, \\
\left.\mathrm{CMe}_{3}\right), 1.81-2.92(\mathrm{~m}, \\
\left.\mathrm{CH}_{2}-\mathrm{CH}_{2}-\mathrm{CH}_{2}\right), 6.46 \\
(\mathrm{~s}, \mathrm{NH}), 7.20-8.12 \\
(\mathrm{~m}, \mathrm{Ar}-\mathrm{H})\end{array}$ & $\begin{array}{l}\mathrm{C}_{\mathrm{q}}: 141.6,135.0, \\
131.4,125.4,115.4, \\
49.6 ; \mathrm{CH}: 128.5, \\
128.1,127.5,127.3, \\
126.5,125.3,124.1, \\
122.3,119.1,115.3 ; \\
\mathrm{CH}_{2}: 35.4,33.0,27.4 ; \\
\mathrm{CH}_{3}: 33.5,3.6,2.8\end{array}$ & -11.1 & $\begin{array}{l}886\left[\mathrm{M}^{+}\right], 871\left[\mathrm{M}^{+}-\right. \\
\mathrm{Me}], 835\left[\mathrm{M}^{+}-\mathrm{Me}-\mathrm{Cl}\right], \\
798\left[\mathrm{M}^{+}-\mathrm{Me}-2 \mathrm{Cl}\right], \\
756\left[\mathrm{M}^{+}-\right. \\
\left.\mathrm{Me}_{2} \mathrm{SiNHBu}^{\mathrm{t}}\right]\end{array}$ \\
\hline
\end{tabular}

The ${ }^{29} \mathrm{Si}-\mathrm{NMR}$ spectrum of $\mathbf{1}$ showed a sharp single resonance at $\delta=-11.1 \mathrm{ppm}$.

The mass spectrum of 1 showed the molecular ion peak at $\mathrm{m} / \mathrm{z} 830$ and other peaks for its fragments at $\mathrm{m} / \mathrm{z} 700\left[\mathrm{M}^{+}-\mathrm{SiMe}_{2} \mathrm{~N}(\mathrm{H}) \mathrm{Bu}^{\mathrm{t}}\right], 685\left[\mathrm{M}^{+}-\mathrm{Me}_{2} \mathrm{SiN}(\mathrm{H}) \mathrm{Bu}^{\mathrm{t}}-\mathrm{Me}\right]$ which were characteristic for the formulation of complex 1.

Thus all the experimental evidences strongly support the proposed structure of the sandwich complex 1. Spectroscopic data of the remaining two complexes $\mathbf{2}$ and $\mathbf{3}$ (Table 1) can be similarly explained.

\section{Acknowledgements}

One of the authors (KK) is grateful to the authority of the German Academic Exchange Programme (DAAD) for the award of a short term visiting fellowship to work in the chemical laboratories of the University of Bayreuth, Germany. Grateful 
acknowledgement is also made to Prof. Dr. H. G. Alt of this university for his kind hospitality and helpful discussions.

\section{References}

1 J. A. N. Canich and G. F. Licciard, U S Patent, 1991, 5, 057, 475.

2 R. E. LaPointe, R. K. Rosen and P. N. Nickias, Eur Pat Appl, 1992, 0495375 A2.

3 R. K. Rosen, P. N. Nickias, D. D. Devore, J. C. Stevens and F. J. Timmers, U S Patent, 1994 $5,374,696$.

4 B. A. Harrington, PCT Int Appl, 1996, WO 96/40806.

5 P. N. Nickias, M. H. McAdon and J. T. Patton, PCT Int Appl, 1997, WO 97/15583.

6 H. G. Alt, A. Reb and K. Kundu, J Organometal Chem, 2001, 628, 211.

(Received: 18 September 2010; Accepted : 5 July 2011) 